\title{
Electrolyte membranes based on ultrafine fibers of acetylated cellulose for improved and long-lasting dye- sensitized solar cells
}

\author{
Joice Jaqueline Kaschuk - Kati Miettunen • Maryam Borghei • \\ Elisabete Frollini • Orlando J. Rojas
}

Received: 29 January 2019/ Accepted: 19 May 2019/Published online: 25 May 2019

(C) The Author(s) 2019

\begin{abstract}
Electrospun nanofibers obtained from cellulose acetate before (CA) and after (DCA) deacetylation were used as electrolyte membranes in dyesensitized solar cells. As holders of the active components of the device and compared to the reference system, the CA and DCA membranes increased the average device efficiency by as much as $14 \%$. The membranes enhanced the charge transfer at the counter electrode (assessed by the Ohmic and charge transfer resistance and corresponding Helmholtz capacitance). Simultaneously, the photoelectrode did
\end{abstract}

not interfere with the performance as measured by the short-circuit current density, open circuit voltage, fill factor and conversion efficiency. Long-term stability tests (light soaking) showed that the CA- and DCAbased solar cells sustain operation for at least $500 \mathrm{~h}$. For long term use and/or to serve as a scaffold for other purposes, DCA performs better than CA. The proposed active electrolyte membranes are expected to open the way toward rapid and continuous assembly of dye sensitize solar cells using cellulose esters.

J. J. Kaschuk · E. Frollini ( $₫)$

Macromolecular Materials and Lignocellulosic Fibers

Group, Center for Research on Science and Technology of

BioResources, Institute of Chemistry of São Carlos,

University of São Paulo, CP 780, São Carlos,

São Paulo 13560-970, Brazil

e-mail: elisabete@iqsc.usp.br

J. J. Kaschuk · K. Miettunen · M. Borghei ·

O. J. Rojas (ه)

Department of Bioproducts and Biosystems, School of

Chemical Engineering, Aalto University, Box 16300,

00076 Aalto, Espoo, Finland

e-mail: orlando.rojas@aalto.fi

K. Miettunen · O. J. Rojas

Department of Applied Physics, School of Science, Aalto

University, Box 16300, 00076 Aalto, Espoo, Finland 


\section{Graphical abstract}

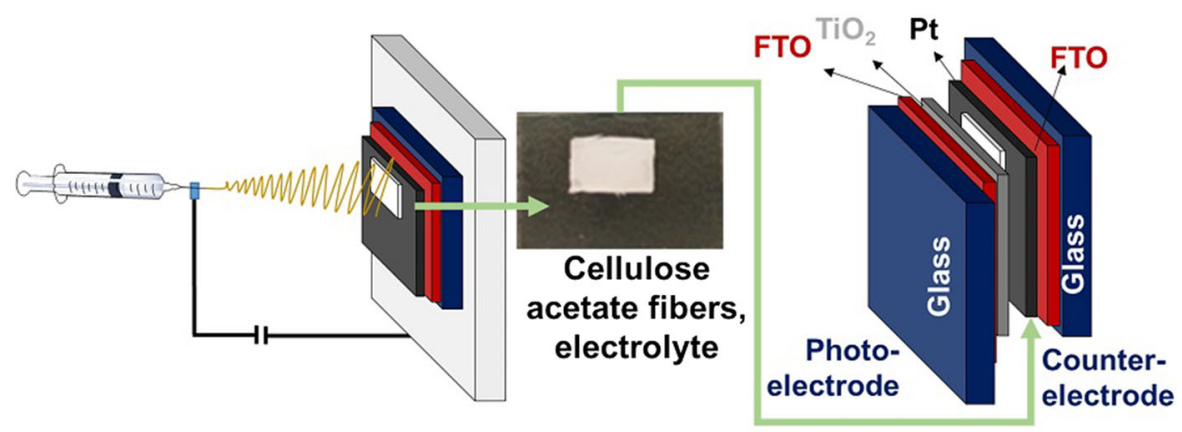

Keywords Photovoltaics - Solar cells - Electrospun membranes $\cdot$ Cellulose acetate $\cdot$ Electrolyte $\cdot$ Stability

\section{Introduction}

Non-toxic, cost-effective and renewable materials, as those produced from cellulose, are becoming increasingly attractive, e.g., in microfiltration membranes (Jalvo et al. 2017) and membrane distillation for treating wastewater (Makanjuola et al. 2019), especially when considering upscaling and lifecycle. Here we propose electrospun fiber webs produced from cellulose esters as electrolyte membranes for third generation solar cells, namely, dye solar cells (Zouhri 2018).

A dye solar cell typically consists of a photoanode electrode coated by titanium dioxide $\left(\mathrm{TiO}_{2}\right)$ layer (semiconductor), a counter electrode as a cathode, a sensitizer (dye), and an electrolyte (Richhariya et al. 2017; Liu and Wang 2019). The operation of such type of solar cell starts with the sensitization of the dye present on the $\mathrm{TiO}_{2}$ surface, followed by the injection of electrons into the conduction band of $\mathrm{TiO}_{2}$, which spread throughout the film moving then to the counter electrode, and thus, generating energy. On the counter electrode, the electrons are collected by the electrolyte and then absorbed by the dye, which leads to the regeneration of the dye at the process end (Gong et al. 2017).

In conventional dye solar cells, cellulosics have been utilized for decades, mainly as component of screen printable pastes that are burned off during device preparation (Dhungel and Park 2010). In addition, lignocellulosics have been demonstrated as components of solar cells upon carbonization, for use as catalyst at the counter electrode (Wang et al. 2014; $\mathrm{Xu}$ et al. 2018; Zhou et al. 2018), or as photoelectrode in the form of cellulose nanofibers (Bella et al. 2017), in sandwiched-type thin films of cellulose/CuInS (Reishofer et al. 2017; Weiß1 et al. 2019), or paperbased substrates (Hashmi et al. 2014; Wang and Kerr 2011). In this contribution, cellulose acetate (CA) is used as membrane material to retain electrolyte in dye solar cells. CA facilitates processing in different solvents. Moreover, the hydrophilic character of CA can be tuned via the degree of substitution in CA synthesis or upon deacetylation of as-produced CA, e.g., in deacetylated (DCA) membranes. Membranes based on electrospun fibers have been used as counterelectrode comprising polyacrylonitrile (PAN) (An et al. 2016; Li et al. 2018a, b). So far, the use of a CA in dye solar cells has been limited to the preparation of counter electrodes with electrospun kesterite $\mathrm{Cu}_{2} \mathrm{ZnSnS}_{4}$ (CZTS) nanofibers using CA as polymer base (Mali et al. 2014).

The adoption of electrolyte membrane for dye solar cells is motivated by the fact that conventional electrolyte filling, i.e., introducing liquid electrolyte through the cell, causes major losses in efficiency and limits upscaling (Miettunen et al. 2009). Such effects cannot be overcome by modification of the electrolyte composition (Miettunen et al. 2012). Nanocellulose membranes mixed with electrolyte can act as hydro- or organogels that press the electrolyte against the photoelectrode, minimizing the path length (Miettunen et al. 2014). By using such membranes, the electrolyte penetrates vertically into the photoelectrode, facilitating transport along a distance in the range of $20 \mu \mathrm{m}$. This contrasts with the conventional method (i.e. electrolyte pumping), where such 
distance is of the order of $>20 \mathrm{~mm}$. This characteristic length, reduced by 1000 -fold, prevents variations in spatial performance. Alternative options for inserting electrolyte include printing techniques, many of which are based on quasi-solid electrolytes using a polymer gelator (Rong et al. 2013; Seo et al. 2014; Wang et al. 2013). Recently, inkjet printing of liquid electrolyte has been demonstrated (Hashmi et al. 2015), but the rapid evaporation of typical solvents, such as acetonitrile, compromises the success of such system. Given the restriction in solvent types that can be utilized in redox couples as printable electrolyte paste, requiring iodine-based ionic liquids, investigation of gel/membranes is very appealing. Recently, we studied a range of biobased cryogels as electrolyteholding membranes in both, quantum-dot (Borghei et al. 2018) and dye-sensitized solar cells (Poskela et al. 2019). Cellulose nanofibers (CNF), TEMPOoxidized CNF, bacterial cellulose, and chitin nanofibers were investigated due to their inherently different surface charges, fibrillar structure and water-holding capabilities. The corresponding free-standing cryogels enabled easy handling and cell assembly, effective electrolyte filling and efficient redox reactions while keeping the solar cell performance on par with or better than reference cells (based on liquid electrolyte). Nevertheless, the preparation of cryo- and aerogels involves freeze- or supercritical drying, which is time-consuming. In order to facilitate manufacturing towards roll-to-roll processes, we propose electrospun porous membranes. For this purpose, cellulose acetate is attractive given its rapid dissolution in appropriate organic solvents, and easy spinnability which eliminates the need for carrier polymers. In addition, electrospinning allows engineering the membrane thickness, porosity and fiber network via appropriate control of solution properties and operation conditions. Here we adopted electrolyte membranes using ultrathin layers comprising electrospun nanofibers of CA or DCA solutions.

\section{Materials and methods}

\section{Materials}

Cellulose acetate (CA) with average $\mathrm{M}_{\mathrm{n}} \sim 30,000$ by GPC, $39.8 \mathrm{wt} \%$ acetyl and impurities $\leq 3.0 \%$ water, $\mathrm{N}$, $\mathrm{N}$ - dimethylacetamide (DMAc), acetone and $\mathrm{NaOH}$ were purchased from Sigma-Aldrich. $\mathrm{TiO}_{2}$ nanoparticle paste (DSL 18NR-T) and light scattering particles (DSL WER2-0) were obtained from Dyesol. An ionomer resin film (Surlyn ${ }^{\circledR} 1702,20 \mu \mathrm{m}$ thickness) from DuPont was used for solar cell assembly. 1-methyl-benzimidazole (NMBI), 1-propyl-3-methylimidazolium iodide (PMII), guanidinium thiocyanate $(\mathrm{GuSCN})$ and, $\mathrm{I}_{2}$ in 3-methoxypropionitrile (MPN) from Sigma-Aldrich were used as electrolyte.

Counter electrode with cellulose acetate membranes

The counter electrode was prepared on fluorine doped tin oxide (FTO, $15 \mathrm{Ohm} / \mathrm{sq}$.) deposited on glass. The catalyst layer was prepared by spreading $5 \mu \mathrm{l}$ of a $10 \mathrm{mM} \mathrm{H}_{2} \mathrm{PtCl}_{6}$ solution in 2-propanol on the substrate and heated at $390{ }^{\circ} \mathrm{C}$ for $20 \mathrm{~min}$. Then, the electrolyte holding membrane was deposited directly on the counter electrode via electrospinning of the CA solution. In order to obtain membranes with specific dimensions $(5 \times 8 \mathrm{~mm})$, the counter electrode was masked using an aluminum foil, Fig. 1. The solution consistency was achieved for electrospinning by

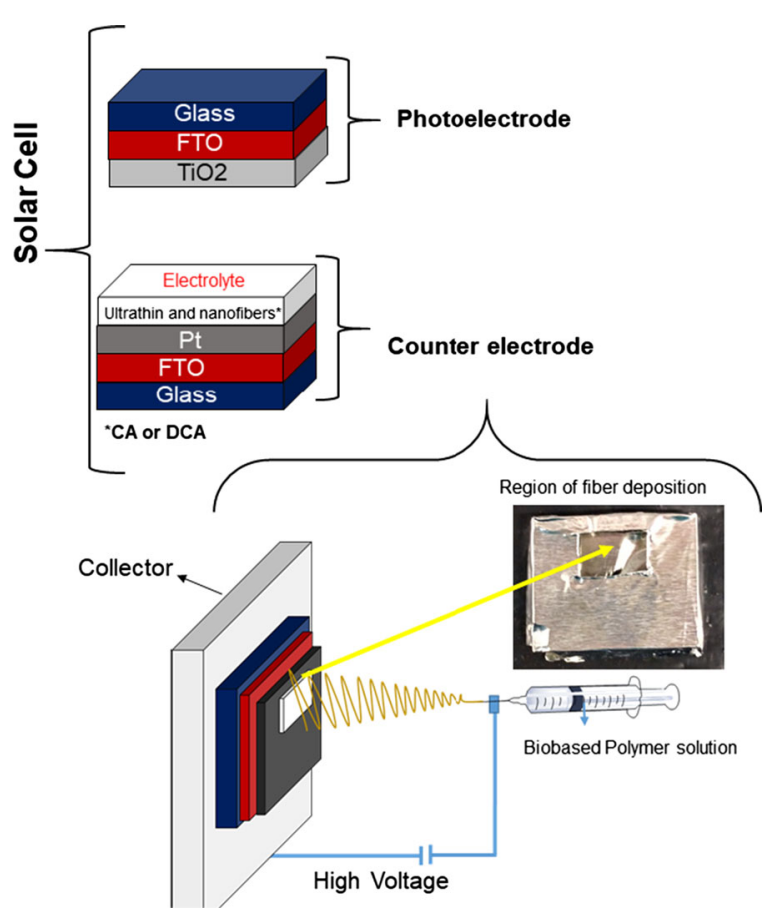

Fig. 1 Configuration of dye solar cells with thin membranes comprising electrospun cellulose acetate (CA) or the corresponding deacetylated (DCA) nanofibers 
dissolving 16\% CA in acetone:DMAc (2:1) (Tungprapa et al. 2007).

A membrane requires a high porosity to retain the electrolyte. In addition, it should properly cover the active region with a suitable thickness so that it does not hamper the solar cell assembly. Therefore, to optimize the fabrication of the CA membrane, the electrospinning process was optimized by varying different parameters such as voltage, flow rate and distance, Table 1.

In order to investigate the interaction of the acetyl groups of the membrane with the electrolyte and their influence on solar cell performance, a deacetylation post-treatment was carried out on the electrospun membranes. Thus, CA membranes were immersed in $\mathrm{NaOH}$ solution $\left(10 \mathrm{~mL}, 0.1 \mathrm{~mol} \mathrm{~L}^{-1}\right)$ during given times $(20,40,60,120,180$ and $240 \mathrm{~min})$ to achieve given degrees of deacetylation. Then, the membranes were taken out and dipped several times in water for washing until reaching the same $\mathrm{pH}$ of wash water.

\section{Photoelectrode preparation}

Photoelectrodes were prepared on FTO-glass. Firstly, the FTO-glass was immersed in a solution of titanium (IV) chloride tetrahydrofuran complex (1 wt $\%)$ in deionized water for $30 \mathrm{~min}$ at $70{ }^{\circ} \mathrm{C}$ and then rinsed with ethanol and distilled water. Following, nanoporous $\mathrm{TiO}_{2}$ layers were screen-printed using an AT-60PD, ATMA screen printer. Two layers of $\mathrm{TiO}_{2}$ nanoparticle paste and one layer of light scattering particles were printed on the FTO-glass substrates. The resulting $\mathrm{TiO}_{2}$ layers were roughly $12 \mu \mathrm{m}$ thick with an area of $0.4 \mathrm{~cm}^{2}$. The $\mathrm{TiO}_{2}$ layers were sintered at $450{ }^{\circ} \mathrm{C}$ and immersed again in a solution of titanium (IV) chloride tetrahydrofuran complex, followed by another sintering step $\left(450{ }^{\circ} \mathrm{C}\right)$. Finally, the photoelectrode was obtained by sensitizing in a dye solution overnight. The dye solution contained $0.2 \mathrm{mM}$ of cisBis(isothiocyanate) (2,2'-bipyridyl-4,4'-dicarboxylate)(4,4'-di-nonyl-2'-bipyridyl)ruthenium(II) (Z907, Dyesol) in 1:1 acetonitrile and tert-butyl alcohol.

Solar cell assembly

The solar cells were assembled by joining photoelectrode and counter electrode/membrane using a framecut thermoplastic (Surlyn) applied as a spacer and sealant under hot-press. Before the cell assembly, the membranes were wetted by $2 \mu \mathrm{L}$ of electrolyte $(0.5 \mathrm{M}$ NMBI, 0.5 M PMII, 0.1 M GuSCN and, 0.1 $\mathrm{M} \mathrm{I}_{2}$ in MPN). For the reference cell (without membrane), the electrolyte was injected through holes drilled on the counter electrodes. Then, the filling holes were covered with another Surlyn foil and thin glass.

Copper tapes were attached on the electrodes as current collector, and then a layer of silver ink (SCP, Electrolube) was painted between the substrates and the copper tapes. After all, a layer of epoxy glue was placed on top of the copper tape and substrate to secure the connections.

Characterization and photovoltaic performance

The membranes were coated by gold and characterized by Scanning Electron Microscopy (SEM - Zeiss Sigma VP). The porosity and the size distribution were evaluated using Image J. Fourier Transform Infrared Spectroscopy (FT-IR) was performed with Nicolet
Table 1 Conditions used in electrospinning experiments

\begin{tabular}{llll}
\hline Experiment \# & Voltage $(\mathrm{kV})$ & Distance $(\mathrm{cm})$ & Flow rate $\left(\mu \mathrm{L} \mathrm{min}{ }^{-1}\right)$ \\
\hline 01 & 15 & 15 & 25.5 \\
02 & 20 & & \\
03 & 25 & & 5.5 \\
04 & 20 & & 15.5 \\
05 & & & 25.5 \\
06 & & & 35.5 \\
07 & & 5 & 25.5 \\
08 & 10 & \\
09 & 15 & \\
10 & & 20 & \\
20 & & & \\
\hline
\end{tabular}


380 equipment (4000-400 $\mathrm{cm}^{-1}, 64$ scans) to determine the degree of substitution. The contact angle measurements were performed using the Contact Angle and Surface Tension Meter: CAM200 (KSV Instruments Ltd., Finland).

The current-voltage measurements were performed using a Peccell PEC-01 solar simulator, with a Xenon lamp that simulated $1000 \mathrm{~W} / \mathrm{m}^{2}$ sunlight at room temperature. The light was calibrated with a PV measurements Inc Si KG5 photodiode. A potentiostat (Keithley $24203 \mathrm{~A}$ Sourcemeter) was used to apply a potential from $-0.3 \mathrm{~V}$ to $0.8 \mathrm{~V}$ and back to $-0.3 \mathrm{~V}$ (i.e., cyclic sweep) with step size of $0.01 \mathrm{~V}$ and a delay of $0.1 \mathrm{~s}$ before $\log$. For this measurement, the solar cells were covered with black tape masks with an aperture $0.5 \mathrm{~mm}$ larger compared to active area of the solar cell. E.g., to prevent any effect of reflected light.

Electrochemical impedance spectroscopy (EIS) was performed with a Zahner Elektrik's IM6 Impedance Measurement unit. The measurements were conducted under illumination of the solar simulator at open circuit voltage, and current frequency range from $0.1 \mathrm{~Hz}$ to $100 \mathrm{kHz}$. The equivalent circuit analysis of impedance spectra was performed with ZView2 software (Scribner Associates, Inc.) utilizing equivalent circuits described before (Halme et al. 2010). The incident photon-to-current efficiency (IPCE) was measured using a QE/IPCE system QEX7 (PV Measurements Inc.) at a wavelength ranging from 300 to $1000 \mathrm{~nm}$, without bias light.

The assembled solar cells were submitted to light soaking stability tests for $500 \mathrm{~h}$. The testing conditions approximated 1 Sun (halogen lamps giving $100 \%$ in the visible range and $20 \%$ in UV range), $40^{\circ} \mathrm{C}$, and ambient relative humidity varying between 10 and $30 \%$. The cells were covered with a UV filter $(400 \mathrm{~nm}$ cut-off, Asmetec $\mathrm{GmbH}$ ) to reduce the long-term effects of UV light. The aging was recorded with a Biologic SP-150 using an Agilent 34980A as a multiplexer. During the stability tests, the cells were kept in open circuit conditions.

\section{Results and discussion}

Optimization of cellulose acetate membranes

Electrospinning at low potential $(15 \mathrm{kV})$ resulted in membranes with a high density of micrometric fibers
(Fig. 2a). As the spinning voltage increased to 20 and $25 \mathrm{kV}$, the diameter of fibers significantly decreased to 100-1000 nm (Fig. 2b, c). The membrane obtained at $20 \mathrm{kV}$ had the largest coverage and porosity $(12.6 \% \pm 2)$; this voltage was selected for further experiments.

The effect of spinning flow rate $(5.5,15.5,25.5$, $35.5 \mu \mathrm{L} \mathrm{min}{ }^{-1}$ ) on fiber morphology and porosity was also assessed. By increasing the flow rate the fiber diameter was reduced to $200-300 \mathrm{~nm}$, Fig. 3. In terms of porosity and coverage, spinning at flow rates of 5.5 and $25.5 \mu \mathrm{L} \mathrm{min}{ }^{-1}$ produced the highest porosity (Fig. 3a, c) while 25.5 and $35.5 \mu \mathrm{L} \mathrm{min}{ }^{-1}$ provided the best coverage (Fig. 3c, d). The fiber mat obtained at $35.5 \mu \mathrm{L} \mathrm{min}{ }^{-1}$ showed weak adhesion to the surface of the counter electrode. The flow rate of $25.5 \mu \mathrm{L} \mathrm{min}{ }^{-1}$ was chosen for further electrospinning studies.

At this point, electrospinning voltage and flow rate were set to the optimized values $(20 \mathrm{kV}, 25.5 \mu \mathrm{L}$ $\min ^{-1}$ ) and the distance between the needle and the collector was adjusted from 5 to $20 \mathrm{~cm}$. A filmogenic material was obtained at $5 \mathrm{~cm}$ (Fig. 4a) with low porosity $(0.9 \% \pm 1.5)$ and heterogeneous fiber size. When the distance was increased to $10 \mathrm{~cm}$ (Fig. 4), a fiber membrane was obtained with diameters mostly between 100 and $400 \mathrm{~nm}$, and the porosity increased to $2.4 \% \pm 4$. When the distance increased to $15 \mathrm{~cm}$ (Fig. 4), the porosity became the largest $(12.6 \% \pm 2)$; however, the fibers mostly remained in the range of $100-400 \mathrm{~nm}$. This membrane also presented higher number of fibers nanometric scale $<100 \mathrm{~nm}$. Finally, spinning using a $20-\mathrm{cm}$ distance led to the membrane with a lower porosity $(7.3 \% \pm 2)$, containing fibers slightly shifted to the larger diameter than the one obtained at $15 \mathrm{~cm}$. CA electrospinning at $25.5 \mu \mathrm{L} \mathrm{min}{ }^{-1}, 20 \mathrm{kV}$ and $15 \mathrm{~cm}$ distance between the needle and the collector provided appropriate conditions to synthesize highly porous and interconnected membranes.

\section{Membranes deacetylation}

During testing of the solar cell assembly, it was observed that the CA membranes dissolved after prolonged time in contact with 3-methoxypropionitrile (MPN), the solvent holding the solar cell electrolyte. We note that the function of the membrane is to retain the electrolyte until the solar cell is properly 
Fig. 2 SEM images of electrospun CA fibers on counter electrodes (left) and the corresponding value of porosity and histograms of fiber diameter (right) for membranes obtained at a spinning potential of a $15 \mathrm{kV}, \mathbf{b} 20 \mathrm{kV}$ and c $25 \mathrm{kV}$
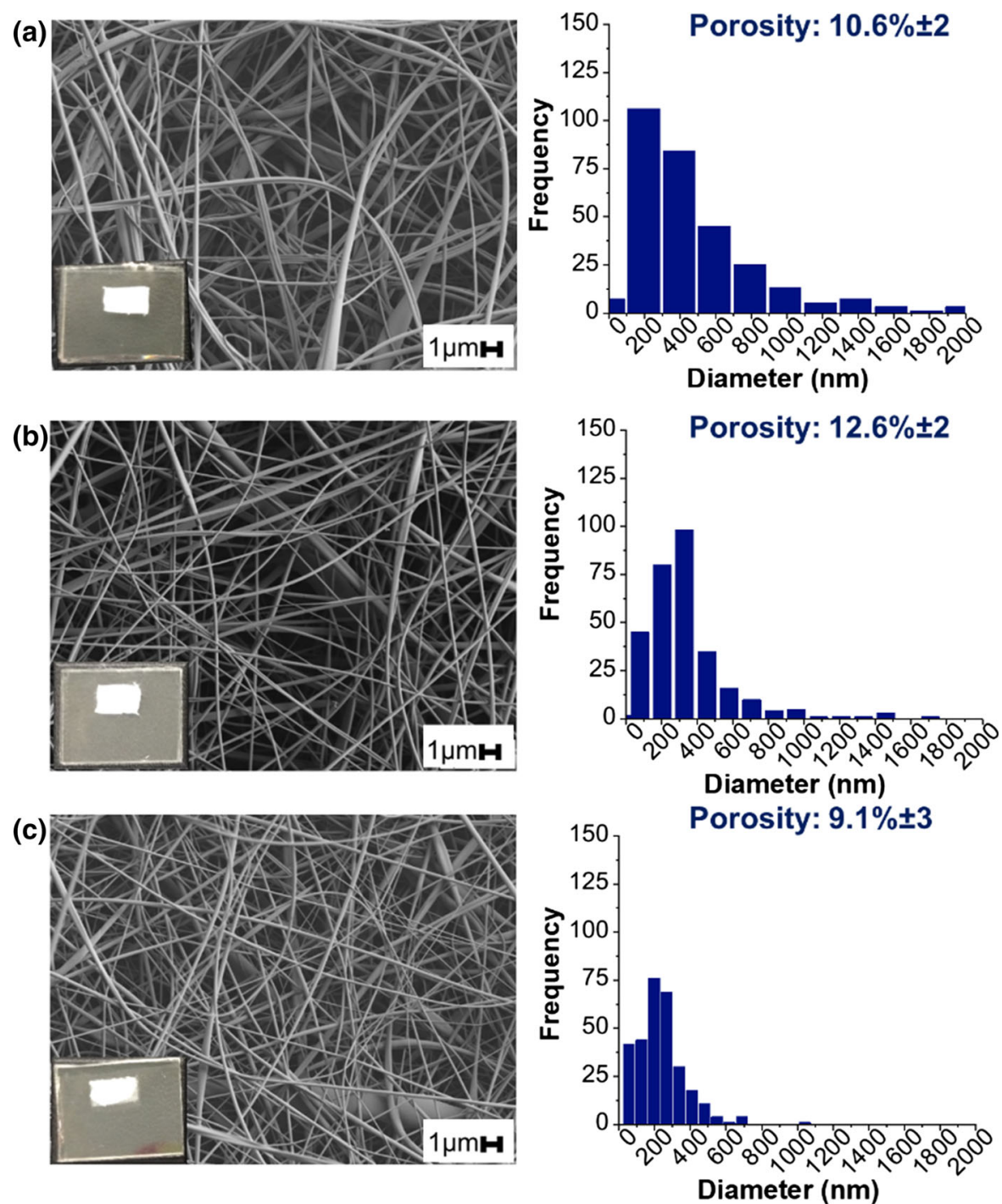

sealed and, therefore, dissolution thereafter does not matter unless it interferes with the operation of the device. However, if the membrane is also to act as a scaffold for other functions, it should hold the system together. Keeping in mind this latter purpose, electrospun CA membranes were subjected to deacetylation for 20-240 $\mathrm{min}$ by immersion in alkaline solution $\left(0.1 \mathrm{~mol} \mathrm{~L}^{-1} \mathrm{NaOH}\right)$. FTIR spectra and SEM images were obtained to evaluate the corresponding changes in chemistry and fibers morphology (Fig. 5).

Alkaline treatment for 120 min increased the band intensity at ca. $3400 \mathrm{~cm}^{-1}$, related to the absorption of the hydroxyl group. The band intensity at ca. $1700 \mathrm{~cm}^{-1}$, corresponding to the carbonyl group, decreased significantly. After $120 \mathrm{~min}$, the carbonyl group band disappeared, indicating total deacetylation, that is, at this time a cellulosic membrane was formed. We note that due to the insolubility of cellulose in common solvents, it is very difficult to directly obtain cellulosic membranes by electrospinning.

The SEM images show that increasing the alkaline treatment time, especially after $40 \mathrm{~min}$, led to some fiber fusion (Fig. 5). The hydrophilic/hydrophobic character and interfacial affinity of the membranes were qualitatively evaluated with measurements of the contact angles with water and MPN. The membrane remained unchanged when contacted with water. 
Fig. 3 SEM images of CA electrospun fibers on counter electrodes (left) and the corresponding value of porosity and diameter histograms (right) for membranes obtained at a spinning flowrate of a 5.5, b 15.5 , c 25.5 and d 35.5 $\mu \mathrm{L} \min ^{-1}$ (a)
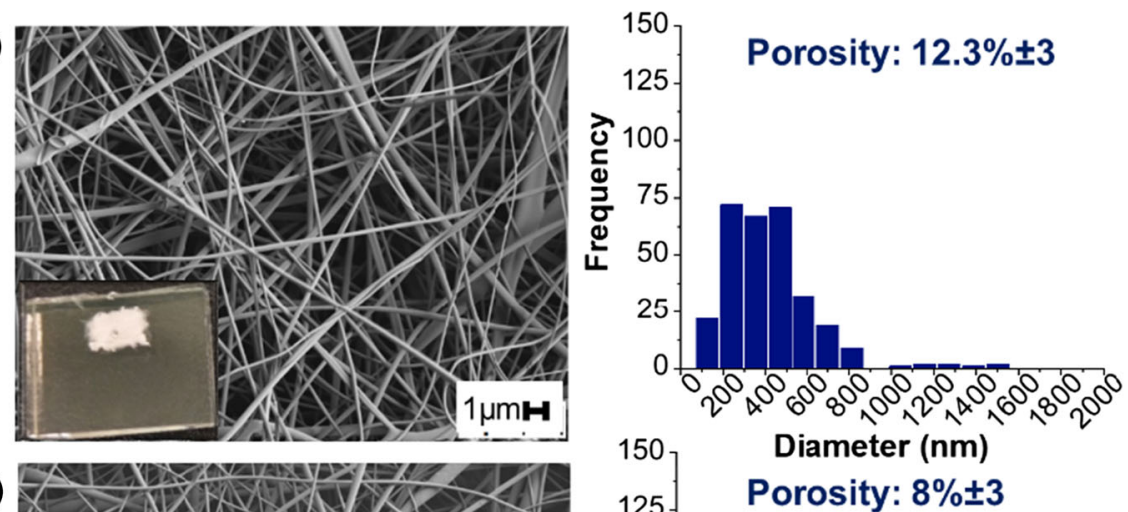

(b)
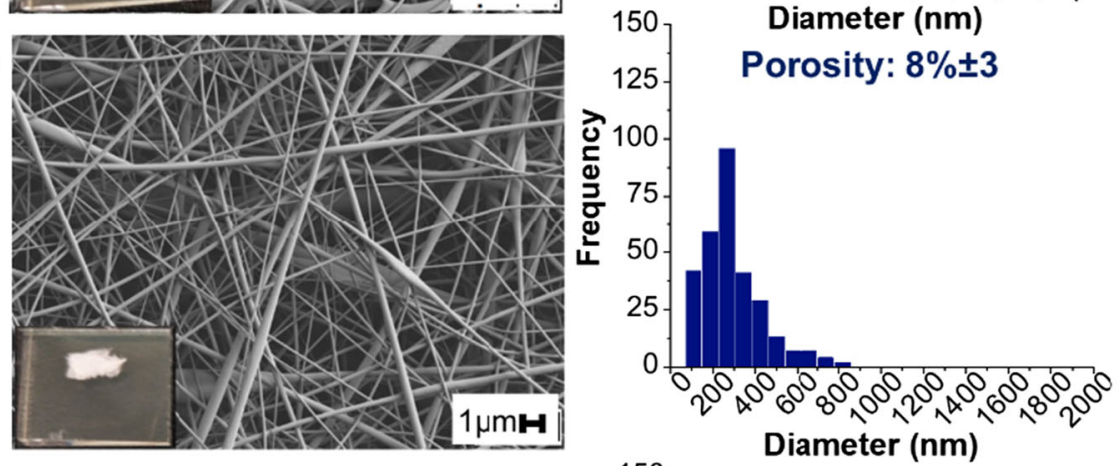

(c)
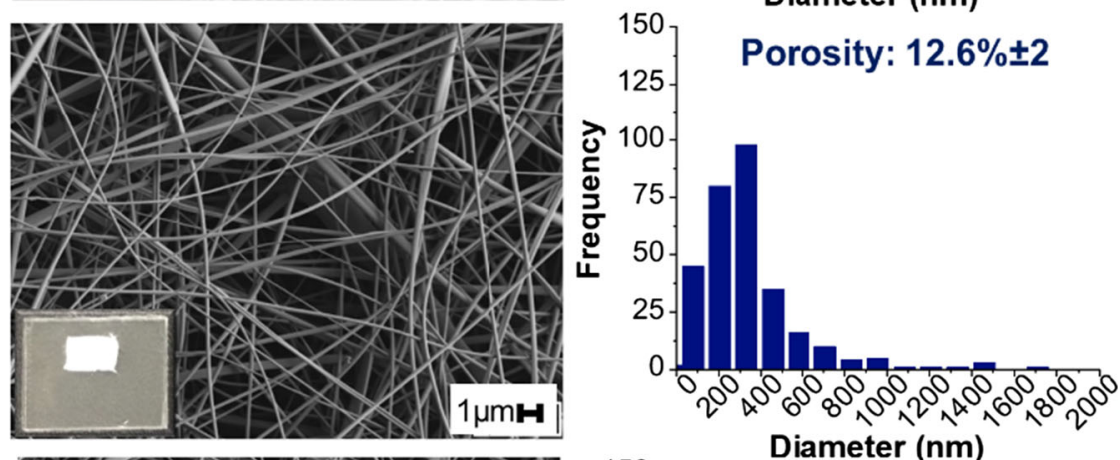

(d)

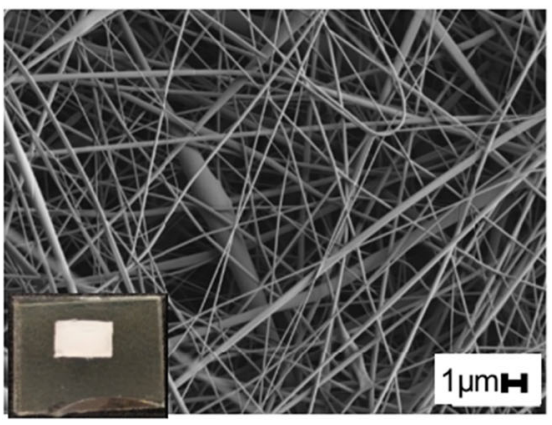

Diameter (nm)

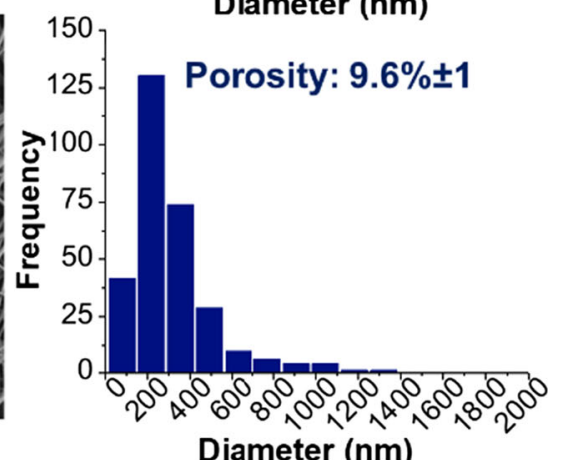

However, some minor membrane dissolution was observed in the presence of MPN for $<120 \mathrm{~s}$, preventing a meaningful assessment of the contact angle with this solvent. For comparison, the contact angle of the membranes is presented in Fig. 6. The contact angles were evaluated after a time of contact equivalent to $600 \mathrm{~s}$ for water and $60 \mathrm{~s}$ for MPN. The time used for MPN is related to the longest period the MPN drop remained unchanged on the surface of the membranes. As observed in Fig. 6, under more severe alkaline treatment, the water contact angle of the membrane gradually decreased from $70^{\circ}$ (for 
Fig. 4 SEM images of CA electrospun fibers on counter electrodes (left), and the corresponding value of porosity and diameter histogram (right) for membranes obtained at a spinning distance between the needle and the collector of: a $5 \mathrm{~cm}, \mathbf{b} 10 \mathrm{~cm}$, c $15 \mathrm{~cm}$, and d $20 \mathrm{~cm}$ (a)

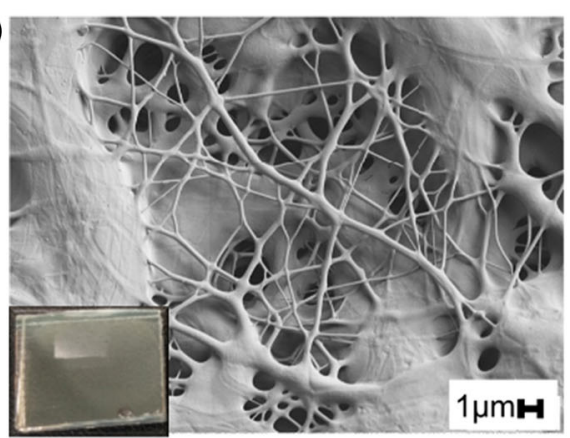

(b)

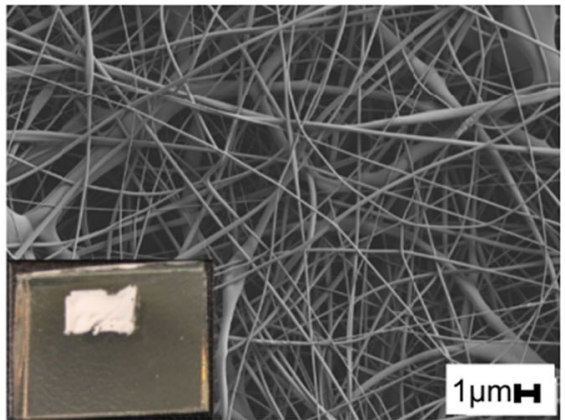

(c)

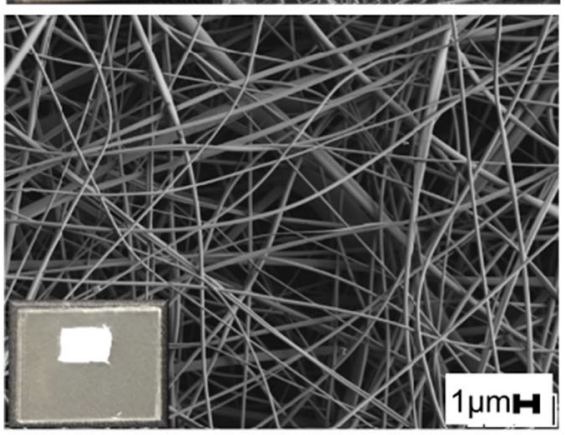

(d)

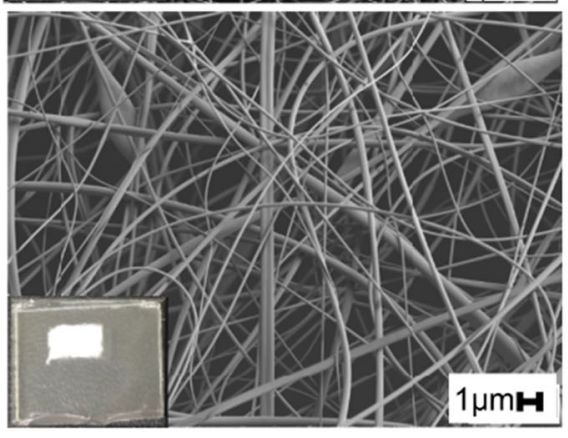

Porosity: $0.9 \% \pm 1.5$

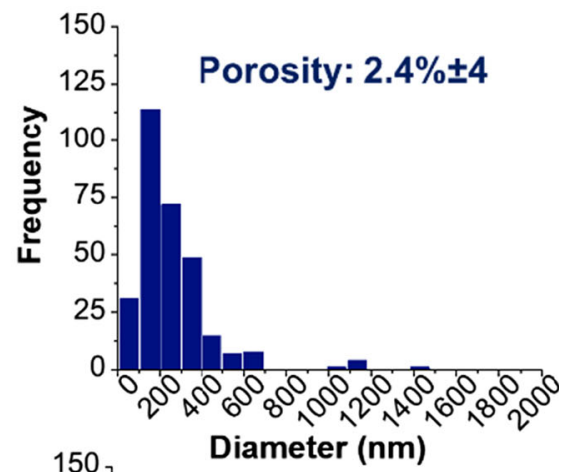

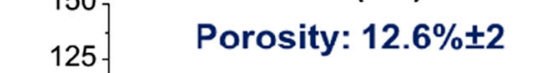

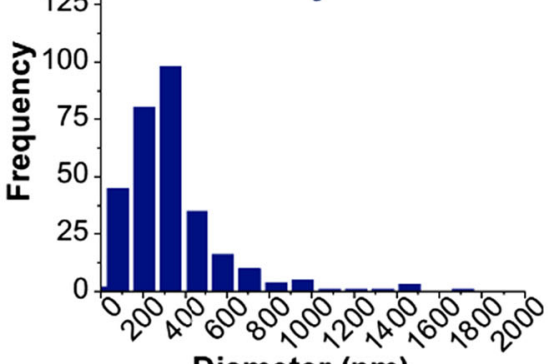

Diameter (nm)

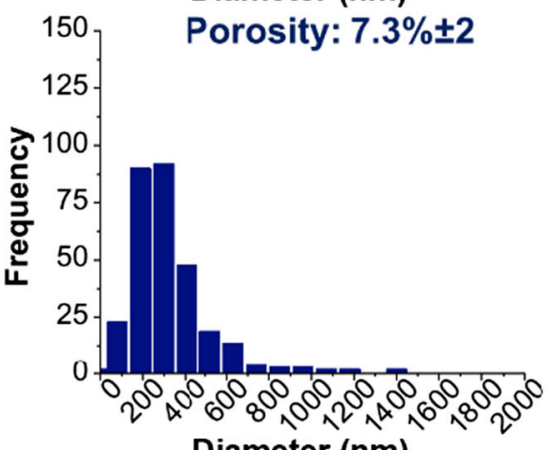

untreated) to $\sim 35^{\circ}$ (for $240 \mathrm{~min}$ ), as explained by the higher density of hydroxyl groups on the surface. The MPN contact angle showed little change for membranes treated for up to $60 \mathrm{~min}$, after which partial dissolution occurred. For more severe deacetylation, from 120 to $180 \mathrm{~min}$, the MPN contact angle increased due to the reduced number of acetyl groups. 


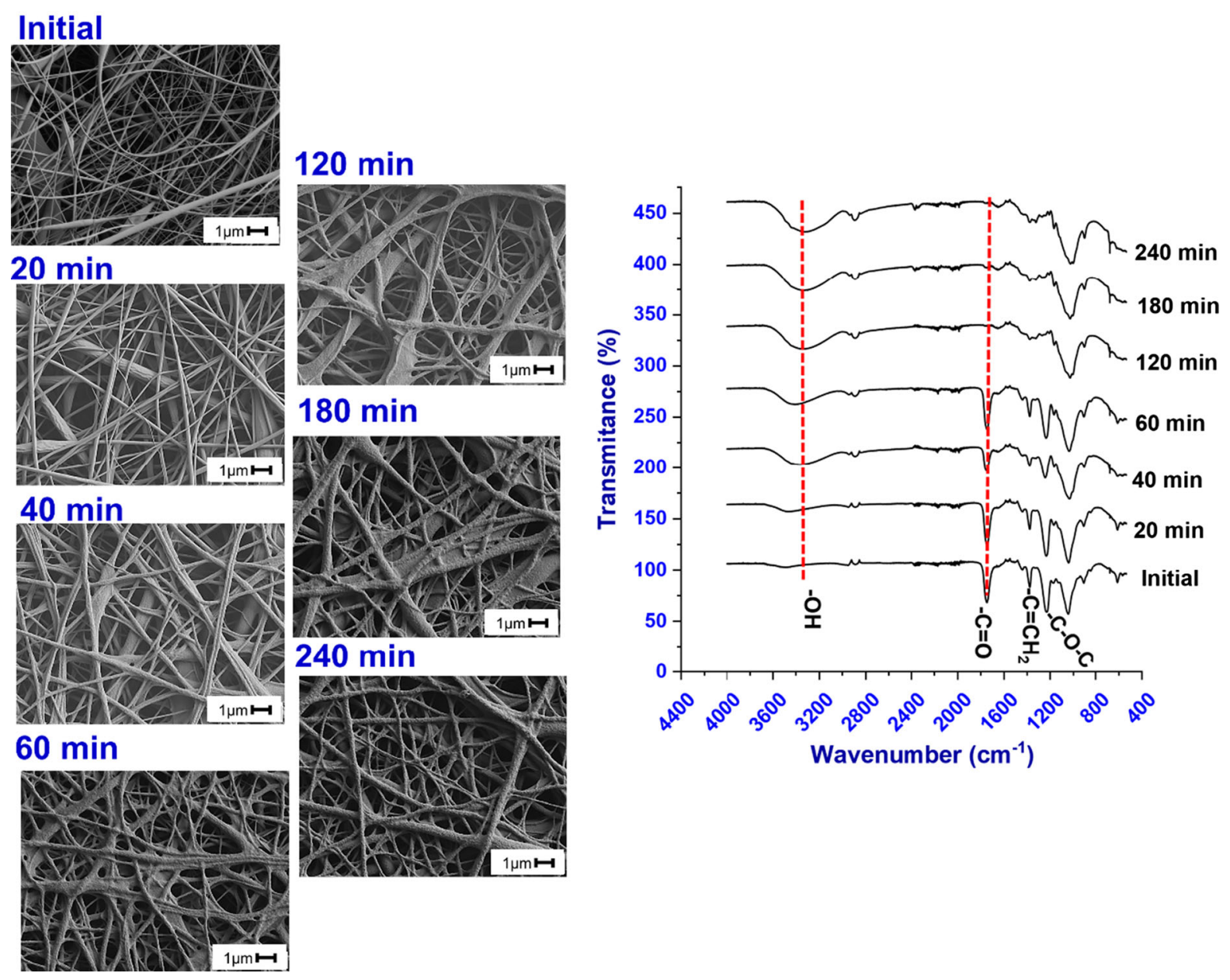

Fig. 5 SEM images and FTIR spectra for electrospun membranes after deacetylation using $\mathrm{NaOH}\left(0.1 \mathrm{~mol} \mathrm{~L}^{-1}\right)$ during the given treatment time

Photovoltaic performance

The solar cells were assembled using the two types of membranes to test the effect of acetyl group on their performance. The CA membrane obtained at optimized electrospinning conditions is referred to as " $\mathrm{CA}$ cell". The one obtained after deacetylation of CA (alkaline treatment for $180 \mathrm{~min}$ ), is referred to as "DCA cell" (Fig. 7). To realize the effect of the membrane and for comparison purposes, reference cells were also assembled with the same liquid electrolyte (in the absence of membrane). For each type (CA, DCA and reference cells), five solar cells were assembled, and their photovoltaic performance were evaluated (see Table 2 with average values and standard deviation).
Both, CA and DCA cells, performed better than the reference cell (see photovoltaic parameters in Table 2). Though the photocurrent $\left(I_{\mathrm{SC}}\right)$ was somewhat similar for all the cells, the open circuit voltage $\left(V_{\mathrm{OC}}\right)$ and fill factor $(\mathrm{FF})$ were improved for CA and DCA cells. The higher $V_{\mathrm{OC}}$ value is possibly due the more uniform distribution of the electrolyte within the membrane in contact with the electrode interface. In the reference cell the electrolyte is filled by pumping through the filling hole, which causes less uniform adsorption of electrolyte redox ions through the cell. This leads to a variation in the overall cell voltage, and finally to a drop in $V_{\mathrm{OC}}$ for the entire device (Miettunen et al. 2009; 2012). With a cell with small photoactive area (as used here), $V_{\mathrm{OC}}$ losses between the different filling methods are not very large. Our 
Fig. 6 Water (square symbol) and 3-methoxypropionitrile (MPN, circles) contact angles with the electrospun membranes after alkaline treatment during the given times, from 0 min (CA) to 240 (fully deacetylated CS, DCA). The contact angle was recorded at $600 \mathrm{~s}$ and $60 \mathrm{~s}$ upon after contact with water and MPN, respectively

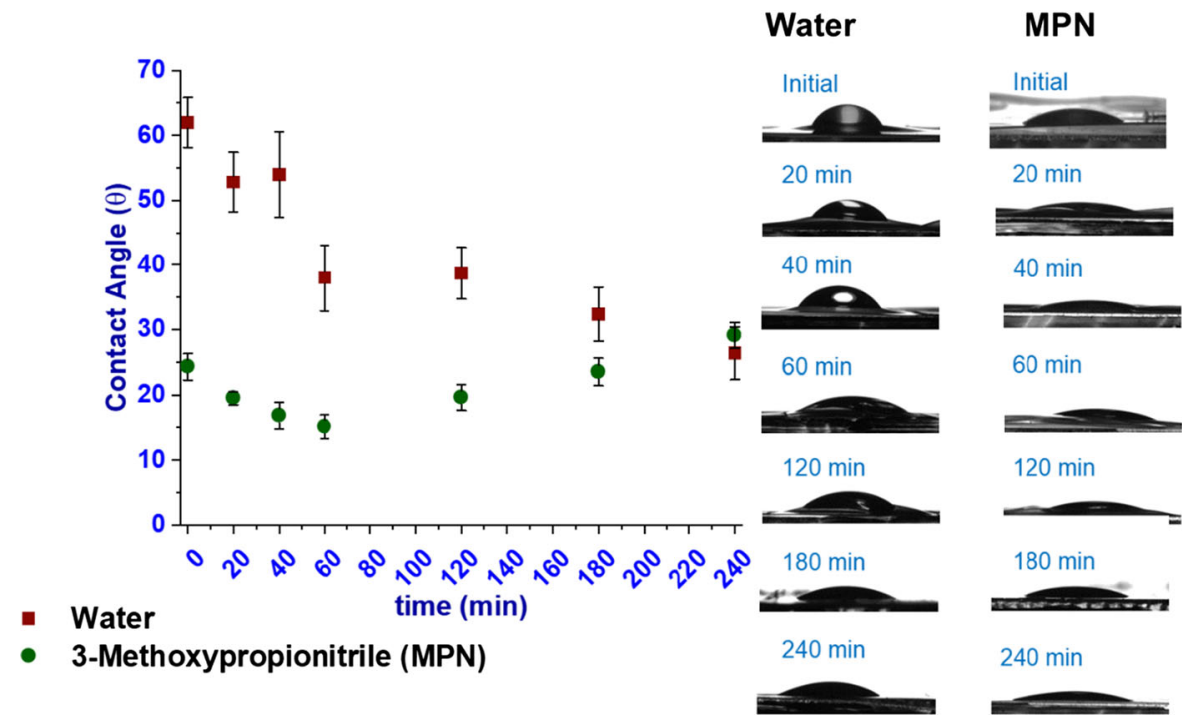

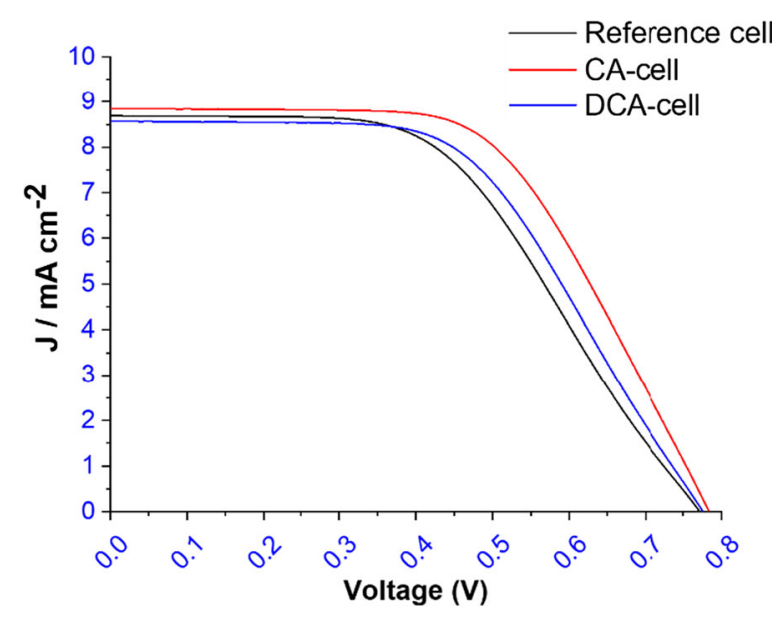

Fig. 7 I-V curve of the solar cells

previous studies have shown that when the length of the photoelectrode was increased from about 1 to $5 \mathrm{~cm}$, the $V_{\text {OC }}$ dropped by $\sim 50 \mathrm{mV}$ (Miettunen et al. 2012).
The incorporation of membranes in the solar cell may hinder the movement of charge carriers in electrolyte, and potentially block some of the catalyst surface on the counter electrode. These effects should increase the resistance related to charge transfer in the electrolyte but also at the electrolyte/counter electrode interface. The increased resistances should cause a reduction in cell FF; however, as Table 2 indicates, the cells comprising the CA and DCA membranes actually improved the fill factor. Similar improvement of charge transfer has been reported even if the membrane or gelator in the electrolyte takes only a small fraction of the total electrolyte volume (Miettunen et al. 2014), such as the CA and DCA membranes do here. Considering the molecular structure of the membrane and under the conditions used in the present study, there is indication that the acetyl groups (CA cells) allow better electron movement compared to DCA cells, which have a higher density of hydroxyls.

Table 2 Photovoltaic parameters of dye-sensitized solar cells comprising membranes of cellulose acetate (CA) and deacetylated CA (DCA) as well as reference cell (with no membrane)

\begin{tabular}{lllll}
\hline & $I_{\mathrm{SC}}\left(\mathrm{mA} \mathrm{cm}^{-2}\right)$ & $V_{\text {OC }}(\mathrm{mV})$ & $F F(\%)$ & $\eta(\%)$ \\
\hline Reference cell & $8.7 \pm 0.3$ & $771 \pm 9$ & $52 \pm 3$ & $3.5 \pm 0.2$ \\
CA cell & $8.8 \pm 0.4$ & $780 \pm 10$ & $58 \pm 2$ & $4.0 \pm 0.2$ \\
DCA cell & $8.6 \pm 0.4$ & $780 \pm 10$ & $55 \pm 2$ & $3.7 \pm 0.1$ \\
\hline
\end{tabular}

$I_{\mathrm{sc}}$ short-circuit current density; $V_{\mathrm{oc}}$ open circuit voltage; $F F$ fill factor; $\eta$ conversion efficiency 
Electrochemical impedance spectroscopy (EIS) was performed in an equivalent circuit model including series resistance $\left(R_{\mathrm{S}}\right)$ and an impedance at the electrolyte/electrode interface $\left(R_{\mathrm{ct}}\right)$ and the related capacitance $C_{\mathrm{CPE}}$.

Table 3 shows that the ohmic resistance, $R_{\mathrm{S}}$, varied for the different cells. $R_{\mathrm{S}}$ is largely dependent on the sheet resistance of the FTO coating on the glass substrates. Typically, variations in $R_{\mathrm{S}}$ arise from the assembly of the device, i.e., slight differences in the positioning of the copper tape and the silver paint are of influence.

The charge transfer resistance at the counter electrode/electrolyte interface, $R_{\mathrm{CE}}$, is useful for understanding the effects of the CA and DCA membranes.

Table 3 shows that the cells containing the membranes had significantly reduced $R_{\mathrm{CE}}$, even though $R_{\mathrm{S}}$ was somewhat higher in the same cells. The smaller $R_{\mathrm{CE}}$ in the cells containing the membrane imply better charge transfer at the counter electrode/electrolyte interface, resulting in a higher $F F$ and conversion efficiency compared to the reference cells (Table 2).

IPCE measurements were carried out and revealed that the cellulose acetate membrane did not affect the function of the photoelectrode. IPCE relates to the number of collected electrons relative to the number of incident photons as a function of the wavelength of the incident radiation, also known as quantum efficiency (QE). As shown in Fig. 8, the maximum QE for all the photocells is about 55\%, mainly in the range of $500-550 \mathrm{~nm}$ and similar in the whole visible range. This indicates that the presence of the CA and DCA membranes did not lead to significant changes neither in the number of generated electrons nor wavelength shift. In other words, the CA and DCA membranes did not interfere with the production of current at the photoelectrode.

Table 3 Ohmic $R_{\mathrm{S}}$ and charge transfer resistance at the counter electrode/electrolyte interface $R_{\mathrm{CE}}$ and corresponding Helmholtz capacitance $C_{\mathrm{CPE}-\mathrm{CE}}$

\begin{tabular}{llll}
\hline & $R \mathrm{~s}(\Omega)$ & $R_{\mathrm{CE}}(\Omega)$ & $C_{\mathrm{CPE}-\mathrm{CE}}(\mu \mathrm{F})$ \\
\hline Reference cells & $12 \pm 1$ & $62 \pm 9$ & $32 \pm 3$ \\
CA cells & $23 \pm 5$ & $34 \pm 14$ & $14 \pm 6$ \\
DCA cells & $16 \pm 3$ & $50 \pm 10$ & $12 \pm 2$ \\
\hline
\end{tabular}

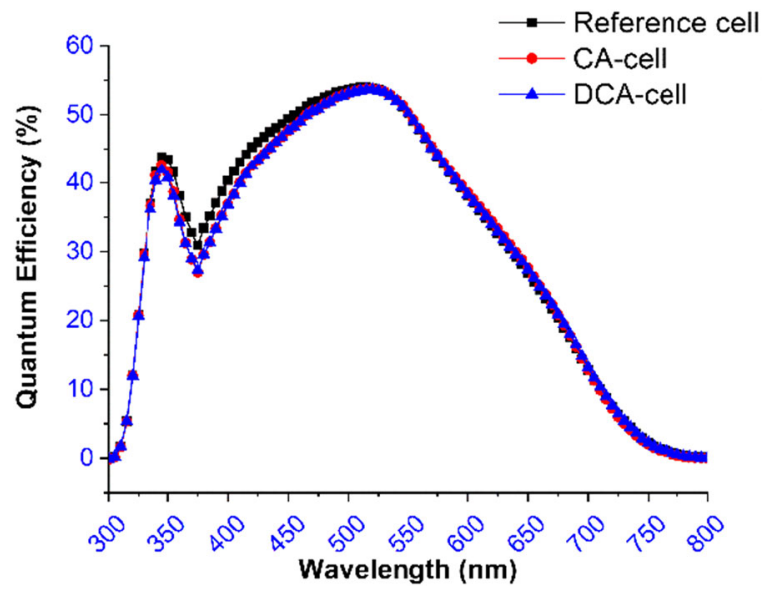

Fig. 8 Profiles corresponding to the incident photon-to-charge carrier conversion efficiency (quantum efficiency, \%) of the solar cells

Photocell stability

To access the influence of the membranes on the longterm performance of solar cells, stability tests were conducted for $500 \mathrm{~h}$ under 1 Sun illumination at $40{ }^{\circ} \mathrm{C}$ (see $I_{\mathrm{sc}}, V_{\mathrm{oc}}, F F$ and $\eta$ in Fig. 9). As shown in Fig. 9, the photovoltaic performance is higher compared to the initial photocell performance reported in Table 2. The higher values of $I_{\mathrm{SC}}$ in the light soaking system can be explained by the fact that no black mask was used, which otherwise reduced the stray light in the solar simulator but caused cell overheating. The cell performance stabilized during the first few hours after assembly due to the complete penetration of the electrolyte in the mesoporous $\mathrm{TiO}_{2}$ layer, which typically shows as higher photocurrent and overall efficiency (Feng et al. 2016). As can be observed from Fig. 9, all the cell types maintained more than $90 \%$ of their initial overall efficiency, at least during $500 \mathrm{~h}$ operation. As indicated in other sections, in the longterm, CA may partially dissolve in MPN solution. This needs to be considered when there is a need for the membrane to hold its structure after assembly.

During aging tests, some variation in the characteristics of the given solar cell is expected. For all the cells, $V_{\mathrm{OC}}$ decreased while $I_{\mathrm{SC}}$ and $F F$ increased. However, typically, the overall efficiency did not vary as much since the changes that occurred in other parameters offset each other. 
Fig. 9 Long-term stability performance $\left(I_{\mathrm{sc}}, V_{\mathrm{oc}}, F F\right.$ and $\eta$ ) of DSC-embedded membranes compared to the reference cell, under 1 Sun light soaking at $40{ }^{\circ} \mathrm{C}$
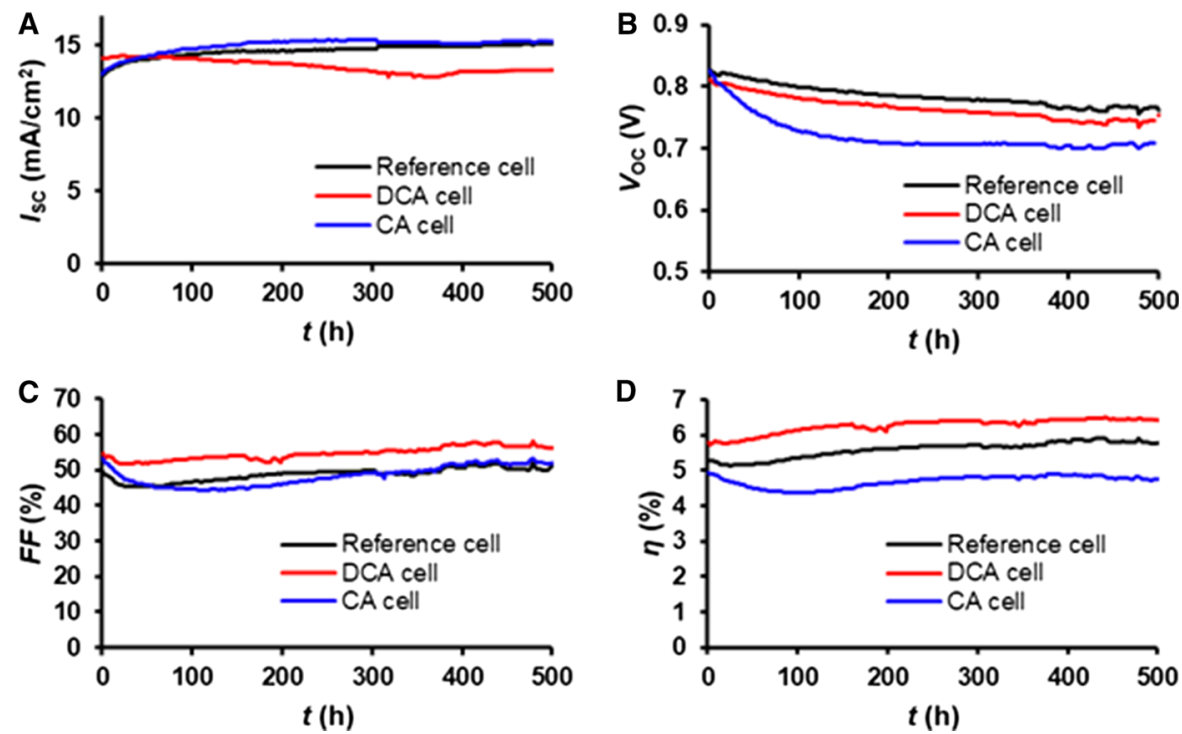

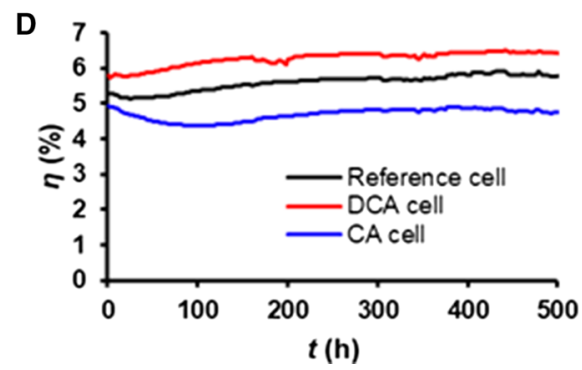

\section{Conclusions}

Electrospun webs of cellulose acetate (CA) and deacetylated CA are proposed as electrolyte membranes for dye solar cells. The membranes improved by $14 \%$ the overall efficiency and reached similar stability compared to standard devices. The membranes improved the charge transfer at the counter electrode/electrolyte interface and did not to interfere with the photocurrent production of the device. Moreover, long term stability was observed in aging tests. Overall, the results suggest that CA and DCA membranes are suitable to overcome the drawbacks that exist in device assembly based on liquid electrolyte filling. The use of electrolyte membranes produced by a simple electrospinning process in dye-sensitized solar cells may be considered in future developments, which require a detailed cost assessment.

Acknowledgments Open access funding provided by Aalto University. Joice Jaqueline Kaschuk is grateful to the Research Internships Abroad (BEPE) program funded by São Paulo Research Foundation - FAPESP (Process 2017/13500-2). Elisabete Frollini gratefully acknowledge CNPq (National Counsel of Technological and Scientific Development, Brazil) for a research productivity fellowship. Kati Miettunen thanks Kone Foundation and Academy of Finland (project BioEST, 318557). This work is connected to the Academy of Finland's Flagship Programme under Projects No. 318890 and 318891 (Competence Center for Materials Bioeconomy, FinnCERES).

Open Access This article is distributed under the terms of the Creative Commons Attribution 4.0 International License (http:// creativecommons.org/licenses/by/4.0/), which permits unrestricted use, distribution, and reproduction in any medium, provided you give appropriate credit to the original author(s) and the source, provide a link to the Creative Commons license, and indicate if changes were made.

\section{References}

An G-H, An H, Ahn H-J (2016) Ruthenium nanofibers as efficient counter electrodes for dye-sensitized solar cells. J Electroanal Chem 775:280-285. https://doi.org/10.1016/ j.jelechem.2016.06.014

Bella F, Pugliese D, Zolin L, Gerbaldi C (2017) Paper-based quasi-solid dye-sensitized solar cells. Electrochim Acta 237:87-93. https://doi.org/10.1016/j.electacta.2017.03. 211

Borghei M, Miettunen K, Greca LG, Poskela A, Lehtonen J, Lepikko S, Tardy BL, Lund P, Subramanian V, Rojas OJ (2018) Biobased aerogels with different surface charge as electrolyte carrier membranes in quantum dot-sensitized solar cell. Cellulose 25(6):3363-3375. https://doi.org/10. 1007/s10570-018-1807-2

Dhungel SK, Park JG (2010) Optimization of paste formulation for $\mathrm{TiO}_{2}$ nanoparticles with wide range of size distribution for its application in dye sensitized solar cells. Renew Energy 35(12):2776-2780. https://doi.org/10.1016/j. renene.2010.04.031

Feng W, Li Y, Du J, Wang W, Zhong X (2016) Highly efficient and stable quasi-solid-state quantum dot-sensitized solar cells based on a superabsorbent polyelectrolyte. J. Mater. Chem. A 4(4):1461-1468. https://doi.org/10.1039/ C5TA08209A

Gong J, Sumathy K, Qiao Q, Zhou Z (2017) Review on dyesensitized solar cells (DSSCs): advanced techniques and research trends. Renew Sustain Energy Rev 68(Part 1):234-246. https://doi.org/10.1016/j.rser.2016.09.097 
Halme J, Vahermaa P, Miettunen K, Lund P, Janne H, Paula V, Kati M, Peter L (2010) Device physics of dye solar cells. Adv Mater 22(35):E210-E234. https://doi.org/10.1002/ adma. 201000726

Hashmi SG, Ozkan M, Halme J, Paltakari J, Lund PD (2014) Highly conductive, non-permeable, fiber based substrate for counter electrode application in dye-sensitized solar cells. Nano Energy 9:212-220. https://doi.org/10.1016/j. nanoen.2014.07.013

Hashmi SG, Ozkan M, Halme J, Misic KD, Zakeeruddin SM, Paltakari J, Grätzel M, Lund PD (2015) High performance dye-sensitized solar cells with inkjet printed ionic liquid electrolyte. Nano Energy 17:206-215. https://doi.org/10. 1016/j.nanoen.2015.08.019

Jalvo B, Mathew AP, Rosal R (2017) Coaxial poly(lactic acid) electrospun composite membranes incorporating cellulose and chitin nanocrystals. J Memb Sci 544:261-271. https:// doi.org/10.1016/j.memsci.2017.09.033

Li L, Lu Q, Li J, Liu X, Shi G, Liu F, Liu S, Ding W, Zhao X, Zhang Y (2018a) Application of rhenium-doped Pt3Ni on carbon nanofibers as counter electrode for dye-sensitized solar cells. Appl Surf Sci 448:522-528. https://doi.org/10. 1016/j.apsusc.2018.04.151

Li L, Zhang X, Wang D, Zhang W, Li X, Zhao X, Zhang Q, Gu L, Yu Z, Wu M (2018b) Electrospinning synthesis of high performance carbon nanofiber coated flower-like MoS2 nanosheets for dye-sensitized solar cells counter electrode. Electrochim Acta 280:94-100. https://doi.org/10.1016/j. electacta.2018.05.113

Liu Q, Wang J (2019) Dye-sensitized solar cells based on surficial $\mathrm{TiO}_{2}$ modification. Sol Energy 184:454-465. https:// doi.org/10.1016/j.solener.2019.04.032

Makanjuola O, Ahmed F, Janajreh I, Hashaikeh R (2019) Development of a dual-layered PVDF-HFP/cellulose membrane with dual wettability for desalination of oily wastewater. J Memb Sci 570-571:418-426. https://doi.org/ 10.1016/j.memsci.2018.10.028

Mali SS, Patil PS, Hong CK (2014) Low-cost electrospun highly crystalline kesterite $\mathrm{Cu} 2 \mathrm{ZnSnS} 4$ nanofiber counter electrodes for efficient dye-sensitized solar cells. ACS Appl Mater Interfaces 6(3):1688-1696. https://doi.org/10.1021/ am404586n

Miettunen K, Halme J, Lund P (2009) Spatial distribution and decrease of dye solar cell performance induced by electrolyte filling. Electrochem Commun 11(1):25-27. https:// doi.org/10.1016/j.elecom.2008.10.013

Miettunen K, Asghar I, Mastroianni S, Halme J, Barnes PRF, Rikkinen E, O'Regan BC, Lund P (2012) Effect of molecular filtering and electrolyte composition on the spatial variation in performance of dye solar cells. J Electroanal Chem 664:63-72. https://doi.org/10.1016/j. jelechem.2011.10.012

Miettunen K, Vapaavuori J, Tiihonen A, Poskela A, Lahtinen P, Halme J, Lund P (2014) Nanocellulose aerogel membranes for optimal electrolyte filling in dye solar cells. Nano Energy 8:95-102. https://doi.org/10.1016/j.nanoen.2014. 05.013

Poskela A, Vapaavuori J, Greca LG, Lehtonen J, Solin K, Ago M, Lund PD, Rojas OJ (2019) Bio-based aerogels aid preparation and improve efficiency of solar cells (submitted)
Reishofer D, Rath T, Ehmann HM, Gspan C, Dunst S, Amenitsch H, Plank H, Alonso B, Belamie E, Trimmel G, Spirk S (2017) Biobased cellulosic-CuInS 2 nanocomposites for optoelectronic applications. ACS Sustain Chem Eng 5:3115-3122. https://doi.org/10.1021/acssuschemeng. 6b02871

Richhariya G, Kumar A, Tekasakul P, Gupta B (2017) Natural dyes for dye sensitized solar cell: a review. Renew Sustain Energy Rev 69:705-718. https://doi.org/10.1016/j.rser. 2016.11.198

Rong Y, Li X, Liu G, Wang H, Ku Z, Xu M, Liu L, Hu M, Yang Y, Zhang M et al (2013) Monolithic quasi-solid-state dyesensitized solar cells based on iodine-free polymer gel electrolyte. J Power Sources 235:243-250. https://doi.org/ 10.1016/j.jpowsour.2013.02.032

Seo S-J, Cha H-J, Kang YS, Kang M-S (2014) Printable ternary component polymer-gel electrolytes for long-term stable dye-sensitized solar cells. Electrochim Acta 145:217-223. https://doi.org/10.1016/j.electacta.2014.09. 016

Tungprapa S, Puangparn T, Weerasombut M, Jangchud I, Fakum P, Semongkhol S, Meechaisue C, Supaphol P (2007) Electrospun cellulose acetate fibers: effect of solvent system on morphology and fiber diameter. Cellulose 14(6):563-575. https://doi.org/10.1007/s10570-007-91134

Wang B, Kerr LL (2011) Dye sensitized solar cells on paper substrates. Sol Energy Mater Sol Cells 95(8):2531-2535. https://doi.org/10.1016/j.solmat.2011.02.032

Wang C, Wang L, Shi Y, Zhang H, Ma T (2013) Printable electrolytes for highly efficient quasi-solid-state dye-sensitized solar cells. Electrochim Acta 91:302-306. https://doi.org/10.1016/j.electacta.2012.12.096

Wang L, Shi Y, Bai X, Xing Y, Zhang H, Wang L, Guo W, Wang N, Ma T, Grätzel M (2014) From marine plants to photovoltaic devices. Energy Environ Sci 7(1):343-346. https://doi.org/10.1039/C3EE42767F

Weiß1 M, Rath T, Sattelkow J, Plank H, Eyley S, Thielemans W, Trimmel G, Spirk S (2019) Multi-layered nanoscale cellulose/CuInS2 sandwich type thin films. Carbohydr Polym 203:219-227. https://doi.org/10.1016/j.carbpol.2018.09. 063

Xu S, Liu C, Wiezorek J (2018) Renewable biowastes derived carbon materials as green counter electrodes for dye-sensitized solar cells. Mater Chem Phys 204:294-304. https:// doi.org/10.1016/j.matchemphys.2017.10.056

Zhou M, He J, Wang L, Zhao S, Wang Q, Cui S, Qin X, Wang R (2018) Synthesis of carbonized-cellulose nanowhisker/ FeS2@reduced graphene oxide composite for highly efficient counter electrodes in dye-sensitized solar cells. Sol Energy 166:71-79. https://doi.org/10.1016/j.solener.2018. 01.089

Zouhri K (2018) The effect of iodide and Tri-iodide on the dye sensitized solar cell. Renew. Energy 126:210-225. https:// doi.org/10.1016/j.renene.2018.03.045

Publisher's Note Springer Nature remains neutral with regard to jurisdictional claims in published maps and institutional affiliations. 